\title{
EVALUATING THE EMPLOYMENT SITUATION OF GRADUATES: A STUDY AT DONG THAP UNIVERSITY
}

\author{
Nguyen Van Canh", Nguyen Quoc Vu, Le Thi Bich Van \\ Dong Thap University
}

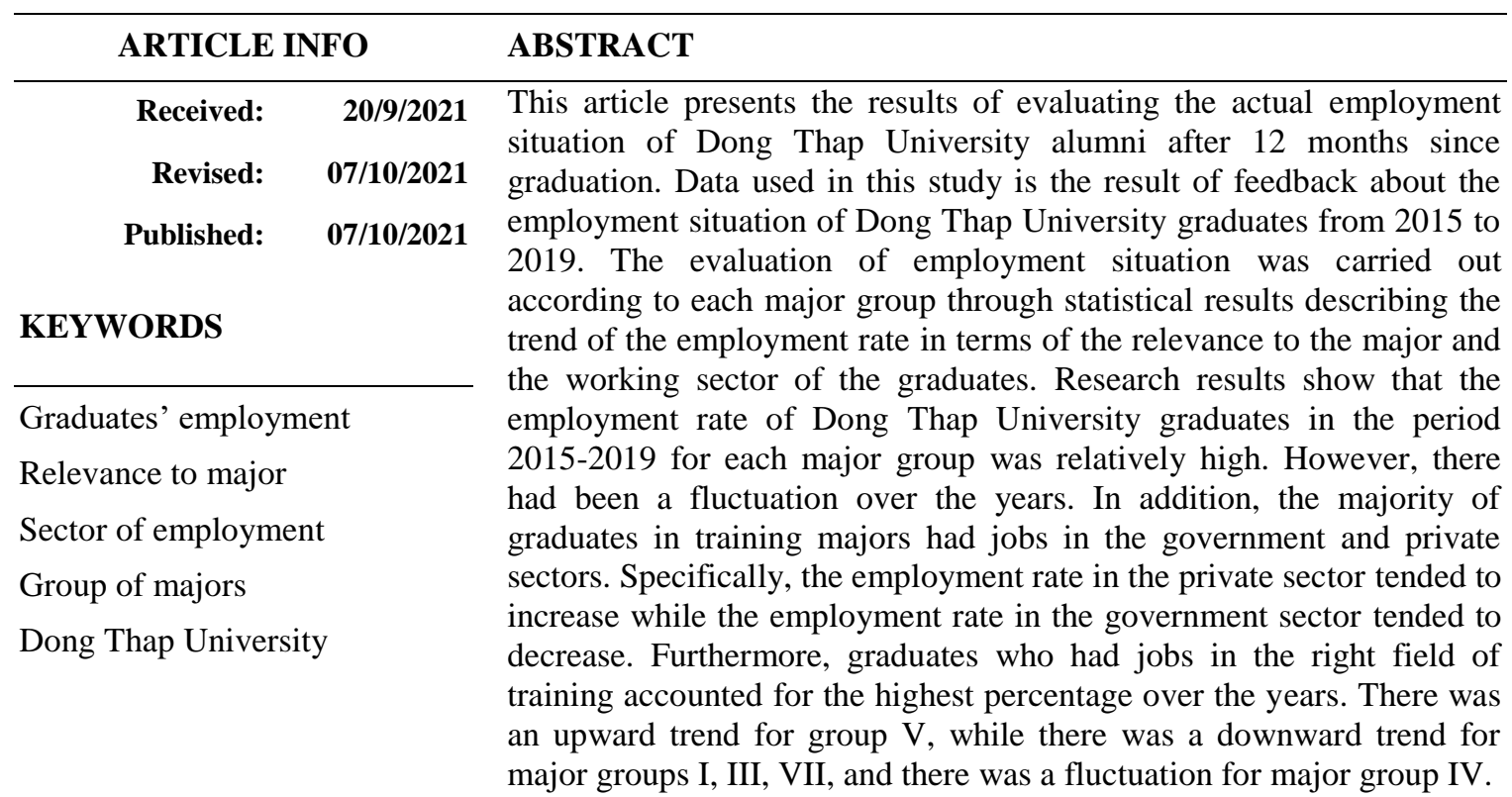

\section{ĐÁNH GIÁ THỬC TRANG VIÊC LÀM CỦA SINH VIÊN TỐT NGHIẸP: NGHIÊN CÚU TẠI TRƯỜNG ĐẠI HỌC ĐỒNG THÁP}

Nguyễn Văn Cảnh", Nguyễn Quốc Vũ, Lê Thị Bích Vân

Truờng Đại học Đồng Tháp

\begin{tabular}{|c|c|}
\hline & \\
\hline $\begin{array}{rr}\text { Ngày nhận bài: } & 20 / 9 / 2021 \\
\text { Ngày hoàn thiện: } & 07 / 10 / 2021 \\
\text { Ngày đăng: } & 07 / 10 / 2021\end{array}$ & $\begin{array}{l}\text { Bài viết trình bày kết quả đánh giá th } \\
\text { viên Trường Đại học Đồng Tháp sau } \\
\text { nghiên cứu là kết quả phản hồi về việc } \\
\text { giai đoạn } 2015-2019 \text {. Việc đánh giá thự } \\
\text { theo từng nhóm ngành đào tạo thông } \\
\text { hướng tỷ lệ việc làm theo mức độ liên }\end{array}$ \\
\hline $\begin{array}{l}\text { Việc làm của sinh viê } \\
\text { nghiệp } \\
\text { Mức độ liên quan đến } \\
\text { Khu vực việc làm } \\
\text { Nhóm ngành đào tạo } \\
\text { Đại học Đồng Tháp }\end{array}$ & $\begin{array}{l}\text { giai đoạn } 2015-2019 \text { đối với từng nhóm ngành đều đạt mức khá cao } \\
\text { mặc dù có sự dao động qua các năm. Ngoài ra, phần lớn sinh viên tốt } \\
\text { nghiệp ở các nhóm ngành đào tạo đều có việc làm thuộc khu vực nhà } \\
\text { nước và tư nhân, trong đó tỷ lệ việc làm thuộc khu vực tư nhân có xu } \\
\text { hướng tăng nhưng tỷ lệ việc làm thuộc khu vực nhà nước có xu hướng } \\
\text { giảm. Bên cạnh đón, sinh viên tốt nghiệp có việc làm đúng ngành đào } \\
\text { tạo chiếm tỵ lệ cao nhất qua các năm, trong đó có xu hướng tăng đối } \\
\text { với nhóm ngành } V \text {, có xu hướng giảm đối với các nhóm ngành I, III, } \\
\text { VII và có sự dao đông đối với nhóm ngành IV. }\end{array}$ \\
\hline
\end{tabular}

DOI: https://doi.org/10.34238/tnu-jst.5062

*Corresponding author. Email: nvcanh@dthu.edu.com 


\section{Introduction}

The employment of students after their graduation is a significant issue and attracts the whole society's attention. Finding a job that is their favourite and related to their training major is the dream of many students after graduation and many school students preparing to enter universities. In recent times, the job demand in the labour market has dramatically changed while the number of graduates from universities is increasing every year, so the job opportunities for graduates have become more and more scanty. The reality shows that not all graduates, even those who have graduated from prestigious universities, can find jobs, especially jobs relevant to their training fields. Therefore, improving the quality of training to meet the requirements of society is an urgent task today for higher education institutions. According to the Vietnam Ministry of Education and Training [1], every year, higher education institutions have to publicize the quality assurance conditions such as facilities, lecturing staff, training programs, and announcement of the graduates' employment status. These are necessary conditions for higher education institutions to be granted enrollment quotas by the Ministry of Education and Training for every new school year. In addition, the public announcement of the employment rate of graduates is an important prerequisite for educational institutions to promote their training brands to the society to attract the attention of parents and students who are going to apply for college or university admission. In order to evaluate the effectiveness of training activities as well as the employment situation of graduates, some studies have been conducted at universities as a basis for adjusting teaching activities, updating training programs to meet the requirements of the labour markets better, helping to increase the employment possibilities of students after graduation. Specifically, in her study, Pham Thi Lan Phuong [2] found the job areas of pedagogical graduates of Ho Chi Minh City University of Education and the factors influencing students' reasons for choosing jobs after graduation. In addition, some studies have been carried out to evaluate the employment situation of graduates applicable to some specific training majors in some universities [3] - [8]. The research projected by Truong Ngoc Thang [9] evaluated the level of relevance between the field of training and the current employment of graduates. Several other studies determine the factors affecting students' job-seeking skills after graduation and propose methods to develop job-seeking skills after graduation [10] - [13]. There are studies on how social networks affect graduates' jobseeking results [14], [15]. In addition, some studies analyzed the roles of social networks in helping graduate employment [16], [17]. Dong Thap University is a public and growing university. With the motto "Quality is first", the university's leaders and all working staff attach great importance to improving the quality of training to create human resources and meet the requirements of society. Every year, the university makes a public report on quality assurance on training conditions, with the employment rate of graduates included, and publishes it on its website. However, employment figures are published sporadically from year to year and have not been evaluated as a whole. For the above reason, this study was carried out to evaluate the employment situation of Dong Thap University graduates in the period 2015-2019. The result of this study is a very important background for Dong Thap University to evaluate the effectiveness of training activities and map out appropriate solutions to improve the quality of training and the employment possibilities for graduates.

\section{Research methods}

The data used in this study are the results of a survey on the employment situation of Dong Thap University's graduates from 2015 to 2019 after 12 months since graduation. The surveywas carried out by 02 main methods, including an online survey based on the Google Form tool and direct phone calls to alumni. The average response rate of graduates was over $85 \%$, of which the response rate over the years was over $72 \%$. In addition, the analysis and evaluation of the actual employment situation were conducted according to each group of majors prescribed by the Vietnam Ministry of Education and Training [18]. Currently, Dong Thap University is training 29 majors at university degrees, in which 02 majors that have not been surveyed for employment 
are Technology teacher education (starting enrollment in 2021) and Agriculture studies (by the end of 2021, start job survey). Thus, the remaining 27 majors of Dong Thap University with outgoing graduates in the period 2015-2019 were subdivided into 05 groups, including I, III, IV, $\mathrm{V}$ and VII. There are no training majors in groups II and VI that were being trained at Dong Thap University. The specific majors of Dong Thap University are shown in Table 1.

Table 1. The training majors at Dong Thap University are classified into major groups

\begin{tabular}{ccl}
\hline $\begin{array}{c}\text { Groups of } \\
\text { training majors }\end{array}$ & $\begin{array}{c}\text { Number of } \\
\text { training majors }\end{array}$ & \multicolumn{1}{c}{ Training majors } \\
\hline I & 15 & $\begin{array}{l}\text { Early Childhood Education, Primary education, Political education, } \\
\text { Physical education, Mathematics teacher education, Informatics teacher } \\
\text { education, Physics teacher education, Chemistry teacher education, } \\
\text { Biology teacher education, Literature teacher education, History teacher } \\
\text { education, Geography teacher education, Music teacher education, Arts } \\
\text { teacher education, and English teacher education }\end{array}$ \\
\hline III & 03 & Accounting, Business Administration, Finance-Banking \\
\hline IV & 01 & Environmental Science \\
\hline VII & 02 & Computer Science, Aquaculture \\
\hline & 06 & $\begin{array}{l}\text { Social Work, English linguistics, Chinese linguistics, Culture } \\
\text { Management, Vietnamese Studies, Land Management }\end{array}$ \\
\hline
\end{tabular}

(Source: List of undergraduate majors of Dong Thap University)

In addition, the number of graduates of Dong Thap University from 2015 to 2019 belonging to the training groups with responses to the employment is shown in Table 2 .

Table 2. Statistics on the number of Dong Thap University graduates who had responded on employment status from 2015 to 2019

\begin{tabular}{cccccccc}
\hline \multirow{2}{*}{ Graduation year } & \multicolumn{5}{c}{ Groups of training majors } & \multirow{2}{*}{ Total } \\
\cline { 3 - 6 } \multirow{2}{*}{2015} & Number of graduates & 401 & 169 & 90 & 26 & 95 & 781 \\
& Number of responses & 292 & 169 & 76 & 24 & 84 & 645 \\
\hline \multirow{2}{*}{2016} & Number of graduates & 599 & 190 & 24 & 9 & 73 & 895 \\
& Number of responses & 599 & 190 & 24 & 9 & 73 & 895 \\
\hline \multirow{2}{*}{2017} & Number of graduates & 1230 & 113 & 111 & 44 & 216 & 1714 \\
& Number of responses & 909 & 109 & 111 & 44 & 215 & 1388 \\
\hline \multirow{2}{*}{2018} & Number of graduates & 1094 & 129 & 51 & 53 & 167 & 1494 \\
& Number of responses & 746 & 120 & 43 & 34 & 140 & 1083 \\
\hline \multirow{2}{*}{2019} & Number of graduates & 1320 & 122 & 46 & 93 & 298 & 1879 \\
& Number of responses & 1168 & 122 & 44 & 85 & 287 & 1706 \\
\hline
\end{tabular}

(Source: Report on employment of Dong Thap University graduates)

The participants considered for employment percentage calculation in this study to evaluate the graduates' employment situation of Dong Thap University in the period 2015-2019 are the number of alumni who responded to year-to-year employment surveys (not taking into account the total number of graduates). Besides, according to the Ministry of Education and Training regulations on employment status statistics, graduates studying for their qualifications are considered employed [19]. However, in this study, the statistics on the employment rate of graduates only include those who have jobs in the right to major, related to major and not related to the training major. Thus, the graduates who were studying for further education were not statistically mentioned in this study. 


\section{Findings and discussions}

\subsection{The employment rate of graduates}

Detailed statistics on the employment rate of graduates for each group of majors in Dong Thap University in the period 2015-2019 are shown in Figure 1.

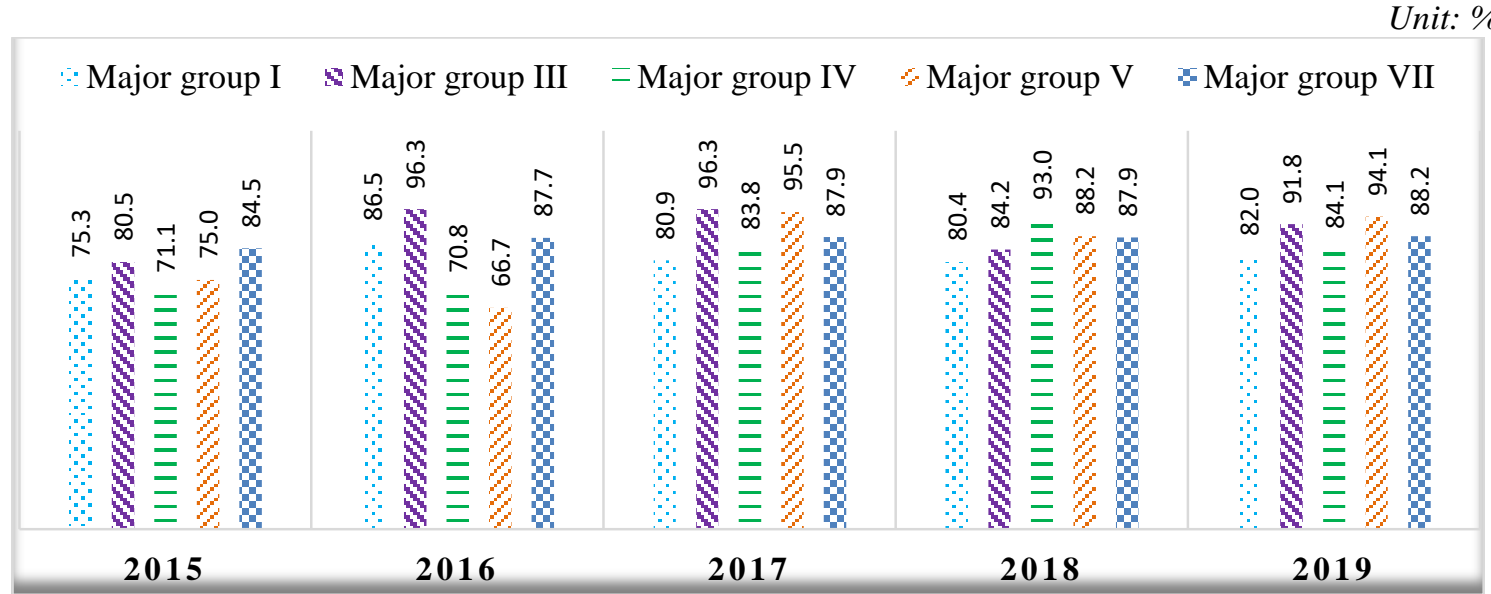

Figure 1. Statistics on the employment rate of Dong Thap University graduates in the period 2015-2019

(Source: Reports on employment of Dong Thap University graduates)

The statistics in Figure 1 show that the percentage of graduates having jobs over the years for each group of training majors was quite high. Specifically, they were from $71.1 \%$ to $84.5 \%$ in $2015,66.7 \%$ to $96.3 \%$ in $2016,81.1 \%$ to $96.3 \%$ in $2017,81.4 \%$ to $93 \%$ in 2018 , and from $81.9 \%$ to $94.1 \%$ in 2019. In addition, the employment rate of graduates in each major group also tended to increase in the period 2015-2019. Specifically, the employment rate in major group I increased from $75.3 \%$ to $82 \%$; major group III rose from $80.5 \%$ to $91.8 \%$; major group IV grew from $71.1 \%$ to $84.1 \%$; major group V climbed from $75 \%$ to $94.1 \%$, and major group VII went up from $84.5 \%$ to $88.2 \%$.

Table 3. Statistics on the employment rate of graduates of training majors in group I

\begin{tabular}{clcccccc}
\hline \multirow{2}{*}{ Number } & \multicolumn{1}{c}{ Training majors } & Mean & \multicolumn{3}{c}{ The employment rate of graduates (\%) } \\
\cline { 5 - 7 } & & $(\mathbf{\%})$ & $\mathbf{2 0 1 5}$ & $\mathbf{2 0 1 6}$ & $\mathbf{2 0 1 7}$ & $\mathbf{2 0 1 8}$ & $\mathbf{2 0 1 9}$ \\
\hline 1 & Biology teacher education & 52.9 & 44.4 & & & & 61.3 \\
2 & Physical education & 67.0 & 28.6 & 74.1 & 71 & 84.2 & 77.3 \\
3 & Physics teacher education & 69.6 & & & & & 69.6 \\
4 & Informatics teacher education & 70.8 & & & & 70.8 \\
5 & History teacher education & 71.1 & & 77.3 & 60 & 76 & 76.4 \\
6 & Political education & 73.4 & 76.9 & 75 & 68.3 & 74.5 & 72.4 \\
7 & Mathematics teacher education & 75.0 & 82.4 & 90.5 & 65.2 & 57.1 & 79.7 \\
8 & Art teacher education & 75.4 & 33.3 & 81.8 & 78.6 & 100 & 83.3 \\
9 & Primary education & 78.0 & 77.1 & 83 & 77.4 & 80.8 & 71.8 \\
10 & Literature teacher education & 81.5 & 96 & 82.9 & 73.7 & 65 & 90 \\
11 & Chemistry teacher education & 83.3 & & 80 & 87 & 86.7 & 79.4 \\
12 & Music teacher education & 83.7 & 75 & 85 & 95.8 & 70.8 & 91.7 \\
13 & Early Childhood education & 87.2 & 76 & 94 & 86.4 & 85.7 & 93.7 \\
14 & Geography teacher education & 88.7 & 88.9 & & & & 88.5 \\
15 & English teacher education & 94.1 & 96.6 & 91.2 & 97.4 & 88.2 & 97.2 \\
\hline
\end{tabular}

(Source: Reports on employment of Dong Thap University graduates) 
The statistics in Table 3 show that the average employment rate of training majors in group I of Dong Thap University from 2015 to 2019 ranged from 52.9\% to $94.1 \%$. In which, graduates of English teacher education had the highest average employment rate while those of Biology teacher education earned the lowest average employment rate. Furthermore, in the period 20152019, some training majors in group I of Dong Thap University did not have graduates because the previous corresponding enrollment course did not have students enrolled. Although the above training majors still attracted 1 or 2 graduates (late graduation) surveyed for employment, they were not representative, so they were not included in the analysis.

Statistics on the employment rate of graduates of training major in the remaining major groups of Dong Thap University are shown in Table 4.

Table 4. Statistics on the employment rate of graduates in groups of major III, IV, V, VII

\begin{tabular}{clcccccc}
\hline \multirow{2}{*}{$\begin{array}{c}\text { Groups of } \\
\text { training major }\end{array}$} & Training majors & Mean & \multicolumn{4}{c}{ The employment rate of graduates (\%) } \\
\cline { 5 - 8 } & \multirow{2}{*}{ III } & (\%) & $\mathbf{2 0 1 5}$ & $\mathbf{2 0 1 6}$ & $\mathbf{2 0 1 7}$ & $\mathbf{2 0 1 8}$ & $\mathbf{2 0 1 9}$ \\
\hline & Business Administration & 90.6 & 83 & 90.7 & & 94.1 & 94.4 \\
& Accounting & 90.6 & 86.3 & 97.8 & 97.2 & 81.7 & 90 \\
& Finance-Banking & 89.3 & 74.6 & 98.3 & 97 & 84.4 & 92.3 \\
\hline IV & Environmental Science & 80.6 & 71.1 & 70.8 & 83.8 & 93 & 84.1 \\
\hline \multirow{2}{*}{ V } & Computer Science & 74.6 & & & & 77.8 & 71.4 \\
& Aquaculture & 86.5 & 75 & 71.4 & 95.3 & 92 & 98.6 \\
\hline \multirow{3}{*}{ VII } & Land Management & 85.0 & 72.4 & 96.8 & 84.2 & 74.4 & 97.4 \\
& Culture Management & 86.6 & & & 94.4 & 84.6 & 80.8 \\
& Social Work & 88.3 & 90.9 & 86.7 & 96 & 83.3 & 84.4 \\
& Vietnamese Studies & 88.8 & 93.3 & 87 & 84.8 & 100 & 79 \\
& English linguistics & 92.1 & 85.7 & & 96.7 & 100 & 85.9 \\
& Chinese linguistics & 96.7 & & & & 93.3 & 100 \\
\hline
\end{tabular}

(Source: Reports on employment of Dong Thap University graduates)

The statistics in Table 4 show that graduates of Dong Thap University in the period 20152019 in major groups III, IV, V, VII all had a high annual employment rate, with an average of $74.6 \%$ or more. Chinese linguistics had the highest average employment rate with $96.7 \%$, and Computer Science had the lowest average employment rate with $74.6 \%$. In addition, some training majors in groups III, V, and VII also had no graduates in the period 2015-2019, or there were just 1 to 2 graduates (late graduation) who were surveyed, so they were not included in the statistics and analysis.

The above analysis data combined with the annual enrollment data of Dong Thap University shows that the employment rate of graduates in major groups was compatible with the number of enrollments in the past years. Specifically, the higher the employment rate of graduates in training disciplines, the higher the enrollment rate and vice versa. This issue was also the general trend of universities in significant competition for jobs in the current labour market, mainly due to low recruitment demand. This situation explained why the rates of graduates' employment in the teacher training group were lower than in other groups, although there was a shortage of teaching teachers at all levels. The results of this study will help education managers plan strategies and policies, adjusting the structure of training professions to suit social realities to solve the current employment problem in teacher training. Specifically, Decree No. 116/2020/ND-CP of Vietnam's Government on policies to support tuition fees and living expenses for pedagogical students, along with the ordering mechanism of localities, will help 
learners avoid a huge waste of effort and finance in studying as well as avoid wasting highly qualified human resources of the society.

\subsection{Relevance of employment to the training major of graduates}

Detailed statistics on the proportion of graduates who have careers based on relation degree to the training major in the period 2015-2019 are shown in Figure 2.

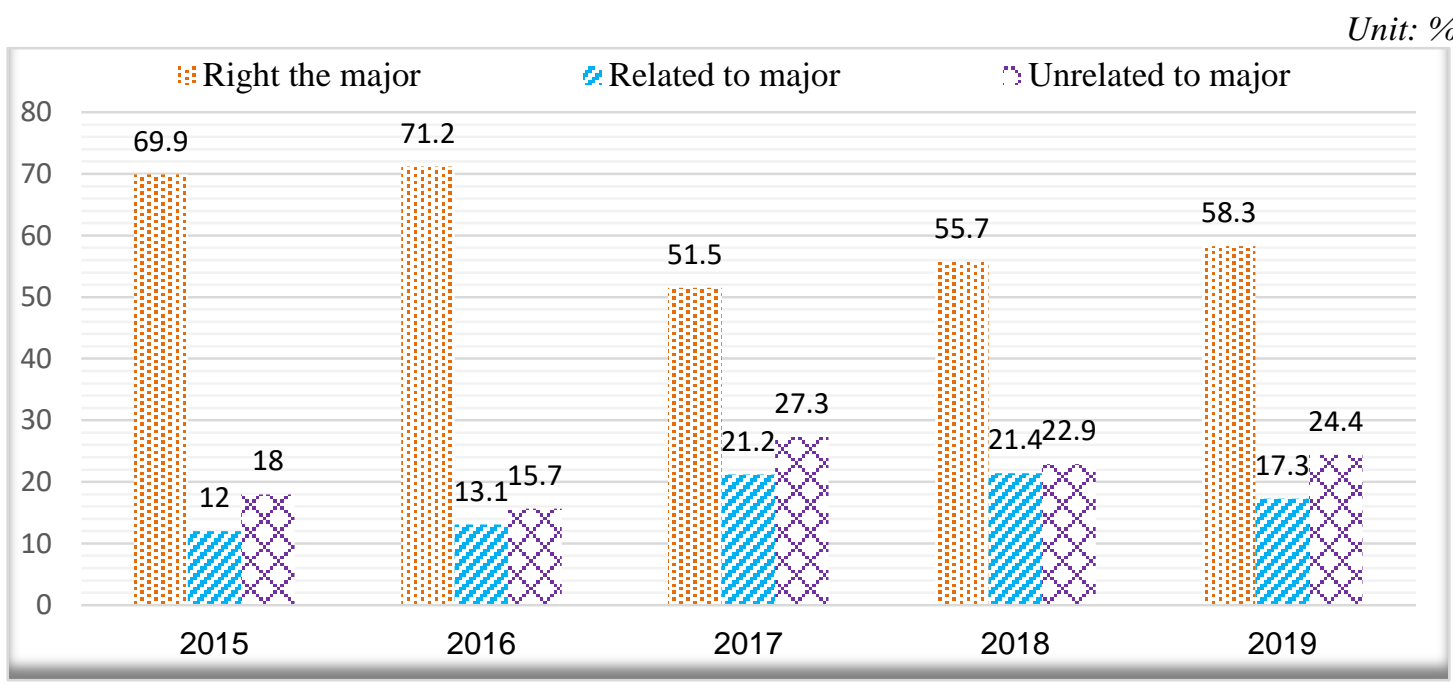

Figure 2. Statistics of graduates' employment rates based on the relevance of major

(Source: Reports on employment of Dong Thap University graduates)

The statistics in Figure 2 show a decreasing trend in the employment rate in the right major and an increasing trend in the jobs related to the major and unrelated to the training major. In addition, the percentage of graduates who had jobs in the right major accounted for the highest rate over the years. The percentage of employment unrelated to the training major was higher than the rate of jobs related to the major in the above period. In 2015, the highest percentage was employment in the right major at $69.9 \%$. Besides, the employment rate unrelated to training major was higher than that of related to training major, at $18 \%$ and $12 \%$, respectively. In addition, the employment rate in the right major tended to drop from 2015 to 2017, an 18.4\% decrease, but there was an upward trend from 2017 to 2019 , a $6.8 \%$ increase. Furthermore, employment data related to the major tended to increase from 2015 to 2018 with an estimated $9.4 \%$, then it decreased and got $17.3 \%$ in 2019 . Finally, employment data unrelated to the major had a continuous fluctuation and reached $24.4 \%$ in 2019.

The statistics in Table 5 show that most graduates of Dong Thap University in a 2015-2019 period from major groups had jobs in the right major, except for graduates of group IV. In addition, the employment rate of graduates in the right major tended to decrease, except for group $\mathrm{V}$ which tended to increase.

For major group I, graduates who had jobs in the right field of study accounted for the highest average rate over the years with $69.8 \%$, while jobs related to the training major accounted for the lowest average rate with $11.8 \%$. In addition, the employment rate in the right major tended to decrease, at $82.3 \%$ in 2015 and $68.1 \%$ in 2019 , respectively. While the graduates' percentage had jobs related to the training major and unrelated to the training major over the years tended to increase. Specifically, the rate of employment related to the training major got 5.5\% in 2015 and $11.3 \%$ in 2019 , respectively. Besides, the employment rates unrelated to the training major got $12.3 \%$ in 2015 and $20.7 \%$ in 2019. For major group III, graduates with jobs in the right field of study accounted for the highest average rate with 54.7\%, and there was a continuous downward 
trend with the corresponding rate of $80.1 \%$ in 2015 and $27.7 \%$ in 2019. In contrast, there was an upward trend in the employment rate related to the training major, with $16.2 \%$ in 2015 and $52.7 \%$ in 2019. In addition, the proportion of employment unrelated to the training majors tended to increase and got $3.7 \%$ in 2015 and $19.6 \%$ in 2019, respectively.

Table 5. The employment rate of graduates in each major group based on relevance to the training major

\begin{tabular}{|c|c|c|c|c|c|c|c|}
\hline \multirow{2}{*}{$\begin{array}{c}\text { Groups of } \\
\text { training major }\end{array}$} & \multirow{2}{*}{$\begin{array}{l}\text { Relevance degree to the } \\
\text { training major }\end{array}$} & \multirow{2}{*}{$\begin{array}{c}\text { Mean } \\
(\%)\end{array}$} & \multicolumn{5}{|c|}{ The employment rate of graduates (\%) } \\
\hline & & & 2015 & 2016 & 2017 & 2018 & 2019 \\
\hline \multirow{3}{*}{ I } & Right the major & 69.8 & 82.3 & 75.5 & 56.9 & 66.3 & 68.1 \\
\hline & Related to the major & 11.8 & 5.5 & 7.9 & 20.7 & 13.8 & 11.3 \\
\hline & Unrelated to the major & 18.4 & 12.3 & 16.6 & 22.4 & 19.8 & 20.7 \\
\hline \multirow{3}{*}{ III } & Right the major & 54.7 & 80.1 & 68.9 & 61.0 & 35.6 & 27.7 \\
\hline & Related to the major & 35.0 & 16.2 & 27.9 & 28.6 & 49.5 & 52.7 \\
\hline & Unrelated to the major & 10.4 & 3.7 & 3.3 & 10.5 & 14.9 & 19.6 \\
\hline \multirow{3}{*}{ IV } & Right the major & 28.4 & 14.8 & 58.8 & 17.2 & 32.5 & 18.9 \\
\hline & Related to the major & 19.9 & 31.5 & 23.5 & 7.5 & 12.5 & 24.3 \\
\hline & Unrelated to the major & 51.7 & 53.7 & 17.6 & 75.3 & 55.0 & 56.8 \\
\hline \multirow{3}{*}{$\mathbf{V}$} & Right the major & 61.1 & 38.9 & 33.3 & 76.2 & 73.3 & 83.8 \\
\hline & Related to the major & 16.2 & 16.7 & 33.3 & 4.8 & 20.0 & 6.3 \\
\hline & Unrelated to the major & 22.7 & 44.4 & 33.3 & 19.0 & 6.7 & 10.0 \\
\hline \multirow{3}{*}{ VI } & Right the major & 41.0 & 62.0 & 50.0 & 36.5 & 23.6 & 32.8 \\
\hline & Related to the major & 22.2 & 8.5 & 7.8 & 29.6 & 38.2 & 26.9 \\
\hline & Unrelated to the major & 36.8 & 29.6 & 42.2 & 33.9 & 38.2 & 40.3 \\
\hline
\end{tabular}

(Source: Reports on employment of Dong Thap University graduates)

For major group IV, graduates with jobs unrelated to the training major accounted for the highest average rate with $51.7 \%$. The lowest rate was jobs related to the training major, with the average rate at $19.9 \%$. In addition, the employment rate in the right major, associated with the major and unrelated to the major, tended to fluctuate over the years. The employment rate in the right field of training got from $14.8 \%$ to $58.8 \%$; the rate of jobs related to the training major was $7.5 \%$ to $31.5 \%$, and the rate of employment unrelated to the training major was $17.6 \%$ to $75.3 \%$. For major group V, Employment in the right field of training of graduates accounted for the highest average rate over the years at $61.1 \%$, and there was an upward in this period at $38,9 \%$ and $83,8 \%$, respectively. In addition, the proportion of jobs unrelated to training majors tended to decrease with $44.4 \%$ in 2015 and $10 \%$ in 2019 . Besides, the employment rate related to training majors fluctuated over the years, but in general, there was a downward trend, 16.7\% in 2015 and $6.3 \%$ in 2019, respectively. For major group VII, there was a big difference in the percentage of graduates who had jobs in the right major, related to the major and unrelated with the training major in 2015, 2016. Still, there was no significant difference in 2017, 2018, and 2019. In addition, there was a downward trend in the average rate of employment in the right major, $62 \%$ in 2015 and $32.8 \%$ in 2019, respectively. Meanwhile, the employment rate related to the training major and not associated with the training major had fluctuated over the years, but there was generally an upward trend. Specifically, the employment rate related to the training major got $8.5 \%$ in 2015 and $38.2 \%$ in 2019 , respectively, and the employment rate unrelated to the training major got $29.6 \%$ in 2015 and $42.2 \%$ in 2019 , respectively.

The analysis results indicated a significant difference in the employment rate unrelated to the training major of group IV graduates (Environmental Science) with other groups. This issue was consistent with the reality of the above major because of the small employment demand in the right major and related to the training major. The research result was an opportunity for the faculty of Agriculture and Environment Resource of Dong Thap University, which is training in Environmental Science, to survey and analyze causes in order to improve the quality of training, 
increase the employment rate of graduates in the right field of training to avoid wasting human resources for society.

\subsection{Work sectors of graduates}

Detailed statistics on the proportion of graduates who had careers based on the work sectors are shown in Figure 3.

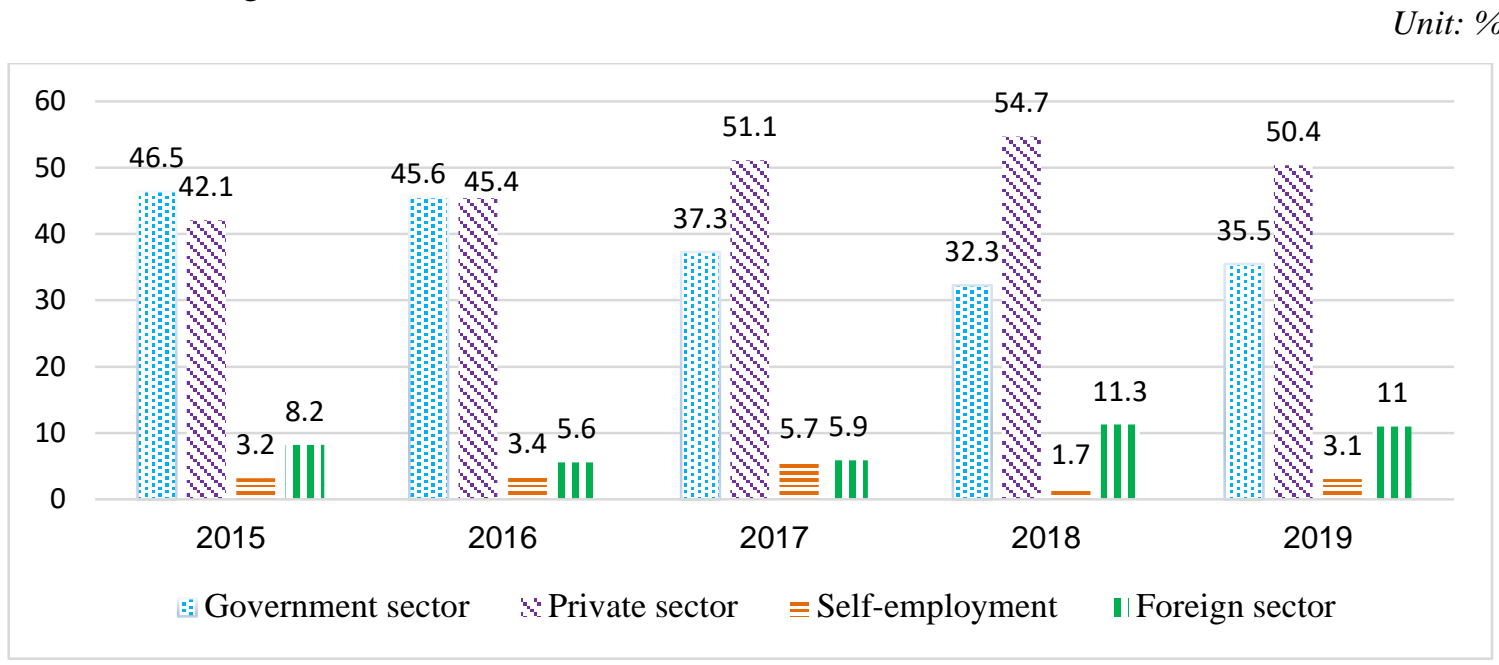

Figure 3. Statistics on the employment rate of graduates based on work sectors

(Source: Reports on employment of Dong Thap University graduates)

The statistics in Figure 3 show that most graduates of Dong Thap University in the period 2015-2019 had jobs in two main sectors, namely private and government. The private sector accounted for the highest employment proportion in this period from $42.1 \%$ to $54.7 \%$, followed by jobs in the government sector, from $32.3 \%$ to $46.5 \%$. In addition, the employment rate of graduates in the private sector tended to increase, while the employment rate in the government sector tended to decrease. Besides, graduates with jobs in the foreign sector increased slightly with $8.2 \%$ in 2015 and $11 \%$ in 2019 . The rest of the graduates self-employed accounted for a low rate and got no more than $5.7 \%$. Detailed statistics on the employment situation of graduates in training major groups of Dong Thap University based on sectors of work in the period 2015-2019 are shown in Table 6.

Overall, most graduates of Dong Thap University in the period 2015-2019 from all training majors had jobs in the private sector, except for graduates of Group I, who had the highest employment rate in the government sector. In addition, the rate of employment in the government sector for the major groups tended to decrease, while the rate of jobs in the private sector tended to increase. Besides, all groups of training majors had the lowest percentage of graduates who had self-employment over the years.

Most graduates had jobs in the government sector for major group I, but there was a downward trend with $79.5 \%$ in 2015 and $46.1 \%$ in 2019 . Meanwhile, the employment rate in the private sector tended to increase at $14.5 \%$ in 2015 and $43.3 \%$ in 2019. Besides, the percentage of graduates working in the foreign sector accounted for a low rate of $8.8 \%$, but there was generally an upward trend. In addition, self-employment by graduates accounted for low over the years with no more than $5.3 \%$. For major group III, graduates with jobs in the private sector accounted for the highest percentage over the years. There was a considerable gap in the employment rate in other sectors. Although there were fluctuations, the employment rate in the private sector tended to increase in this period $2015-2019$, at $64.8 \%$ and $75 \%$, respectively. In addition, the employment rate in the government sector tended to decrease, at $18.4 \%$ in 2015 and $5.4 \%$ in 
2019 , respectively. In contrast, the employment rate of graduates in the foreign sector tended to increase slightly in the period 2016-2019, at 3.3\% and $15.2 \%$, respectively. However, there was a $5.5 \%$ decrease in the employment rate in the foreign sector from 2015 to 2016 . Finally, the graduate's self-employment accounted for a low rate with no more than 5\%.

For major group IV, most graduates had jobs in the private sector, but there was a downward trend with a corresponding rate of $70.4 \%$ in 2015 and $54.1 \%$ in 2019. In addition, the employment rate in the government sector was low, and there was an upward trend, at $9.3 \%$ and $16.2 \%$, respectively. Besides, the employment rate in the foreign sector also tended to increase in this period, at $0 \%$ and $27 \%$, respectively. Furthermore, the graduate's self-employment accounted for a low rate with no more than $5.9 \%$.

For major group V, graduates' employment in the private sector accounted for the highest percentage in this period (from 69\% to 85\%) and tended to rise. In addition, the rate of employment in the government sector and self-employment tended to decrease. Besides, the employment rate in the foreign sector tended to increase in the period 2015-2017, at 5.6\% and $21.4 \%$, respectively. However, there was a $17.6 \%$ decrease in the period 2017-2019. For major group VII, most graduates had jobs in the private sector, and there was an upward trend in the employment rate with $47.9 \%$ in 2015 and $54.9 \%$ in 2019. In addition, there was a downward trend in the employment rate in the government sector from $35.2 \%$ to $20.9 \%$. Furthermore, the employment rate of graduates in the foreign sector tended to increase from $14.1 \%$ in 2015 to $20.6 \%$ in 2019 (although there was a downward trend from 2015 to 2016). Finally, the rate of graduates' self-employment fluctuated and got no more than $3.6 \%$

Table 6. Statistics on the employment rate of graduates of each major group based on work sectors

\begin{tabular}{|c|c|c|c|c|c|c|c|}
\hline \multirow{2}{*}{$\begin{array}{c}\text { Groups of } \\
\text { training major }\end{array}$} & \multirow{2}{*}{ Work sectors } & \multirow{2}{*}{$\begin{array}{c}\text { Mean } \\
(\%)\end{array}$} & \multicolumn{5}{|c|}{ The employment rate of graduates (\%) } \\
\hline & & & 2015 & 2016 & 2017 & 2018 & 2019 \\
\hline \multirow{4}{*}{ I } & Government & 54.5 & 79.5 & 59.5 & 47.2 & 40.2 & 46.1 \\
\hline & Private & 36.22 & 14.5 & 30.9 & 42.9 & 49.5 & 43.3 \\
\hline & Self-employment & 2.98 & 2.7 & 2.9 & 5.3 & 1.5 & 2.5 \\
\hline & Foreign elements & 6.28 & 3.2 & 6.8 & 4.6 & 8.8 & 8.0 \\
\hline \multirow{4}{*}{ III } & Government & 14.12 & 18.4 & 13.7 & 13.3 & 19.8 & 5.4 \\
\hline & Private & 73.12 & 68.4 & 78.7 & 76.2 & 67.3 & 75.0 \\
\hline & Self-employment & 4.22 & 4.4 & 4.4 & 4.8 & 3.0 & 4.5 \\
\hline & Foreign elements & 8.58 & 8.8 & 3.3 & 5.7 & 9.9 & 15.2 \\
\hline \multirow{4}{*}{ IV } & Government & 13.4 & 9.3 & 11.8 & 17.2 & 12.5 & 16.2 \\
\hline & Private & 67.28 & 70.4 & 82.4 & 72.0 & 57.5 & 54.1 \\
\hline & Self-employment & 1.94 & 0.0 & 5.9 & 1.1 & 0.0 & 2.7 \\
\hline & Foreign elements & 17.42 & 20.4 & 0.0 & 9.7 & 30.0 & 27.0 \\
\hline \multirow{4}{*}{$\mathbf{V}$} & Government & 5.22 & 11.1 & 0.0 & 0.0 & 10.0 & 5.0 \\
\hline & Private & 77.24 & 72.2 & 83.3 & 69.0 & 76.7 & 85.0 \\
\hline & Self-employment & 5.38 & 11.1 & 0.0 & 9.5 & 0.0 & 6.3 \\
\hline & Foreign elements & 12.16 & 5.6 & 16.7 & 21.4 & 13.3 & 3.8 \\
\hline \multirow{4}{*}{ VII } & Government & 28.02 & 35.2 & 37.5 & 30.2 & 16.3 & 20.9 \\
\hline & Private & 55.18 & 47.9 & 54.7 & 55.0 & 63.4 & 54.9 \\
\hline & Self-employment & 4.5 & 2.8 & 4.7 & 9.0 & 2.4 & 3.6 \\
\hline & Foreign elements & 12.3 & 14.1 & 3.1 & 5.8 & 17.9 & 20.6 \\
\hline
\end{tabular}

(Source: Reports on employment of Dong Thap University graduates)

The analysis results show that the employment rate of graduates over the years in all major groups was concentrating in the private sector. This issue indicated a change in graduates' attitudes towards choosing a work sector after graduation. Specifically, in the past, most graduates of Dong Thap University, who belong to the Mekong Delta region, got jobs in the 
government sector. But now, there is a definite shift for employment in the private sector. In addition, the graduates also accepted to look for job opportunities in other localities with high job demand, such as Ho Chi Minh City, Binh Duong province, Dong Nai province, where there were many private enterprises and schools. The most valuable proof, in this case, was the graduates of group I. Specifically, the graduates' employment rate of group I in the private sector increased year by year. This issue is consistent with the current trend of educational development in densely populated areas in big cities.

\section{Conclusion}

Training graduates to get jobs is an essential and strategic element in the training activities of higher education institutions. The above factors contribute to the prestige and brand name of higher education institutions, and at the same time, contribute to avoiding economic waste for learners' families and highly qualified human resources of the society. This issue is also the responsibility that universities need to pay special attention to guide the training required by the community. The studies of graduates' employment are meaningful to higher education institutions in managing and organizing training activities and especially meaningful to parents and students in choosing a major before entering university. For Dong Thap University, this research result will be essential for reviewing, researching, and updating the training program to meet the labour market requirements. In addition, Dong Thap University needs to pay more attention to connecting with agencies and businesses to design, update, and develop training programs; especially, there is information about job opportunities to introduce timely to students after graduation.

\section{REFERENCES}

[1] Vietnam's Ministry of Education and Training, "Circular No. 36/2017/TT-BGDDT dated December 28 , 2017, promulgating regulations on government implementation for education and training institutions under the national education system" (in Vietnamese), 2017.

[2] P. L. T. Pham, "Results of the survey on employment of students who graduated from Ho ChiMinh City University of Pedagogy," (in Vietnamese), Ho Chi Minh City University of Education Journal of Science, no. 13 pp. 107-114, 2008.

[3] T. P. T. Nguyen, "Employment situation of graduates of management information system branch at HU - University of Economics," (in Vietnamese), Hue University Journal of Science: Economics and Development, vol. 126, no. 5A, pp. 207-217, 2017.

[4] H. H. T. Nguyen, Y. P. T. Nguyen, and C. N. Nguyen, "Employment reality of student graduated from faculty of Finance - Banking of Van Lang University academic years 1-14," (in Vietnamese), Scientific Journal of Van Lang University, no. 3, pp. 34-43, 2017.

[5] C. V. Do, T. P. Le, H. T. T. Nguyen, and V. X. Tran, "Evaluating the employment situation of accounting graduates from Hung Yen University of Technology and Education," (in Vietnamese), Journal of Science and Technology - Hung Yen University of Technology and Education, no. 18, pp. 75-80, 2018.

[6] T. N. Nguyen and Q. M. N. Ngo, "Evaluating the employment status of the graduates from Quy Nhon University Department of Economics and Accounting," (in Vietnamese), Quy Nhon University Journal Science, vol. 12, no. 2, pp. 47-58, 2018.

[7] L. N. Nguyen, "Jobs for Trade Union University's graduates " (in Vietnamese), Trade Union Scientific Research Magazine, no. 15, pp. 60-64, 2019.

[8] N. T. T. Vu, "The employment of bachelor at Community Services major and several suggestions to develop student's potential," (in Vietnamese), Scientific Journal of Hanoi Metropolitan University, no. 38, pp. 199-205, 2020.

[9] T. N. Truong and X. T. Hoang, "Assessing the relevance of specialized training to the current job of graduated student in the Sociology Department of Trade Union University," (in Vietnamese), Trade Union Scientific Research Magazine, no. 9, pp. 38-43, 2017. 
[10] T. T. Ha, H. A. Hoang, and H. P. Truong, "The method of developing job-seeking skills for graduates of Thai Nguyen College of Economics and Finance," (in Vietnamese), TNU Journal of Science and Technology, vol. 225, no. 04, pp. 85-91, 2020

[11]K. N. T. Phan and H. H. Nguyen, "Job performance and necessary skills for employment after graduate -a case of International Business students in CanTho University," (in Vietnamese), Can Tho University Journal of Science, no. 43, pp. 109-119, 2016.

[12] L. P. Le, P. M. T. Chu, and T. K. T. Nguyen, "Research factors affecting the employability of Foreign Trade University students after graduation," (in Vietnamese), Journal of International Economics and Management - Foreign Trade University, no. 84, pp. 124-135, 2016.

[13]D. N. T. Nguyen and N. H. T. Doan, "Factors influencing the students' ability to be recruited in finance and accounting major, Lac Hong University," (in Vietnamese), Journal of Science of Lac Hong University, no. 6, pp. 126-131, 2019.

[14]C. H. Pham, "Social Networks and the Employment of Graduates," (in Vietnamese), VNU Journal of Science: Social Sciences and Humanities, vol. 30, no. 4, pp. 44-53, 2014

[15] T. T. T. Nguyen, "Social Networks and Sociology Graduates' Employment," (in Vietnamese), VNU Journal of Science: Education Research, vol. 34, no. 1, pp. 12-21, 2018.

[16]T. Q. Pham, "Using some utilities of Google and Facebook in surveying job information of students after graduation at Nha Trang National College of Pedagogy," (in Vietnamese), Vietnam Journal of Education, no. Special issue for July in 2019, pp. 250-255, 2019.

[17]N. L. Nguyen, "The Roles of Facebook in Student Employment Nowadays and Policy Recommendations," (in Vietnamese), VNU Journal of Science: Policy and Management Studies, vol. 36, no. 4 pp. 96-102, 2020.

[18] Vietnam's Ministry of Education and Training, "Consolidated document No. 03/VBHN-BGDĐT dated March 31, 2020: Circular stipulating the determination of enrollment quotas at intermediate and college level in teacher training disciplines; bachelor's, master's, and doctoral degrees" (in Vietnamese), 2020.

[19] Vietnam's Ministry of Education and Training, "Document No. 3943/BGDĐT-GDDH dated August 31, 2018, on Surveying, publicizing, and reporting the employment situation of graduates" (in Vietnamese), 2018. 